\title{
PROSES ACID WASH UNTUK MENURUNKAN KADAR PENGOTOR PADA CAKE HASIL MERRIL CROWE
}

\author{
Tri Wahyuningnsih", Wahyu Pamungkas ${ }^{2}$ \\ Program Studi Teknik Metalurgi - Fakultas Teknologi Mineral \\ UPN “Veteran” Yogyakarta, Jl. Padjadjaran, Condongcatur, Yogyakarta 55283 \\ Email: $116180048 @$ student.upnyk.ac.id \\ $+6285211447833$
}

\begin{abstract}
Indonesia is one of the countries with the largest gold mining potential in the world. Currently, many domestic mining companies have started to process ore from mining, this is based on UU no. 4 tahun 2009 concerning mineral and coal mining. Hydrometallurgy is a separation technique that uses chemical solutions or reagents to capture or dissolve the metal. One form of the hydrometallurgical process is the cyanidation process. The cyanidation process produces gold in the form of a liquid, which must then be re-deposited (recovery). The Merril Crowe process is a solid-liquid separation process and recovery through precipitation and precipitation mechanisms using zinc powder. The Merril Crowe process has several drawbacks that cause the gold recovery from this process to be low and allow additional impurities such as copper to be deposited through the zinc powder used. Therefore, special treatment is needed for the ore resulting from the Merril Crowe process, one of which is the acid wash process using sulfuric acid $\mathrm{H}_{2} \mathrm{SO}_{4}$. The acid wash process can reduce the levels of $\mathrm{Cu}$ and $\mathrm{Zn}$ in the cake produced by Merril Crowe up to $53.31 \%$ and $68.84 \%$, respectively.
\end{abstract}

Keywords: Acid wash, Merril crowe, Gold

\begin{abstract}
Abstrak
Indonesia merupakan salah satu negara dengan potensi tambang emas terbesar di dunia. Saat ini, sudah mulai banyak perusahaan tambang dalam negeri melakukan proses pengolahan bijih hasil tambang, hal ini didasari oleh Undang-Undang No. 4 Tahun 2009 tentang pertambangan mineral dan batubara. Hidrometalurgi merupakan teknik pemisahan yang menggunakan larutan atau reagen kimia untuk menangkap atau melarutkan logamnya. Salah satu bentuk proses hidrometalurgi adalah proses sianidasi. Proses sianidasi mengasilkan emas dalam bentuk cairan, yang kemudian harus diendapkan kembali (recovery). Proses merril crowe merupakan proses pemisahan padatcair dan recovery melalui mekanisme pengendapan dan presipitasi menggunakan serbuk seng. Proses merril crowe ini memiliki beberapa kekurangan yang menyebabkan perolehan emas dari proses ini tergolong rendah dan memungkinkan adanya deposit pengotor tambahan seperti tembaga melalui serbuk seng yang digunakan. Maka dari itu, dibutuhkan perlakuan khusus untuk bijih hasil proses merril crowe ini, salah satunya adalah proses acid wash menggunakan asam sulfat $\mathrm{H}_{2} \mathrm{SO}_{4}$. Proses acid wash dapat menurunkan kadar $\mathrm{Cu}$ dan $\mathrm{Zn}$ dalam cake hasil merril crowe hingga 53,31\% dan 68,84\%.
\end{abstract}

Kata Kunci : Acid wash, Merril crowe, Emas

\section{PENDAHULUAN}

Pertambangan merupakan salah satu upaya untuk memanfaatkan sumber daya alam dengan melakukan suatu kegiatan mulai dari tahap pencarian, penggalian, pengolahan hingga tahap pemasaran hasil tambang. Pertambangan emas memiliki rata-rata produksi tambang emas $13.720,4423 \mathrm{~kg}$ per tahun serta total produksi sebesar $2.501 .845,73 \mathrm{~kg}$ dari tahun 1990 sampai 2011, potensi emas di 
Indonesia tergolong dalam kategori cukup besar.

Saat ini, sudah mulai banyak perusahaan tambang dalam negeri melakukan proses pengolahan bijih hasil tambang, hal ini didasari oleh UndangUndang No. 4 Tahun 2009 tentang pertambangan mineral dan batubara, yang mewajibkan setiap perusahaan pertambangan untuk memurnikan logam di dalam negeri sebelum dijual. Hal ini juga melatar belakangi pembangunan pabrik pemurnian logam di berbagai daerah di Indonesia.

Hidrometalurgi merupakan teknik pemisahan yang menggunakan larutan atau reagen kimia untuk menangkap atau melarutkan logamnya. Teknik ini dapat diterapkan untuk memisahkan logam emas dari bijih emas yang berkadar rendah. Hidrometalurgi dilakukan karena semakin sulitnya ditemukan bijih emas kadar tinggi. Contoh proses hidrometalurgi diantaranya adalah metode sianidasi. Sianida merupakan reagen yang paling sering digunakan untuk mengisolasi emas untuk eksploitasi emas skala industri. Proses sianidasi mengasilkan emas dalam bentuk cairan, yang kemudian harus diendapkan kembali (recovery).

Tahap recovery larutan kaya hasil proses sianidasi umumnya dapat menggunakan beberapa metode kombinasi seperti proses merril crowe, proses adsorsbsi karbon, resin penukar ion, proses electrowinning, dll. PT Nusa Halmahera sendiri menggunakan proses merril crowe untuk proses recovery larutan kaya hasil proses sianidasi. Proses merril crowe merupakan proses pemisahan padatcair dan rekoveri melalui mekanisme pengendapan dan presipitasi menggunakan serbuk seng. Proses merril crowe ini memiliki beberapa kekurangan yang menyebabkan perolehan emas dari proses ini tergolong rendah dan memungkinkan adanya deposit pengotor tambahan seperti tembaga melalui serbuk seng yang digunakan. Maka dari itu, dibutuhkan perlakuan khusus untuk bijih hasil proses merril crowe ini, salah satunya adalah proses acid wash.

Penelitian ini bertujuan untuk memberikan gambaran mengenai pertimbangan metode acid wash untuk mengurangi kadar tembaga yang terdapat pada cake hasil merril crowe agar dore bulion yang dihasilkan pada proses smelting memiliki kadar emas yang lebih tinggi

\section{DASAR TEORI}

\subsection{Merril crowe}

Proses Merrill-Crowe adalah teknik recovery emas dan perak dari larutan hasil sianidasi bijih emas dengan cara mengendapkan ion emas dan perak menggunakan serbuk seng. Larutan hasil sianidasi tersebut telah melalui serangkaian tahap pemisahan padatancairan dengan counter current decantation (CCD) thickener dan filtrasi dengan vacuum filter. Selain itu, sebelum dilakukan proses presipitasi emas dan perak oleh serbuk seng, larutan terlebih dahulu dilakukan deaerasi di dalam Crowe Tower. Proses Merrill Crowe umumnya digunakan ketika bijih yang dilindi memiliki kandungan $\mathrm{Au}$ dan $\mathrm{Ag}$ yang tinggi serta kandungan pengotor yang rendah.

Presipitasi logam emas oleh serbuk seng berlangsung melalui reaksi berikut: 


$$
2 \mathrm{Au}(\mathrm{CN}) 2^{-}+\mathrm{Zn}=2 \mathrm{Au}+\mathrm{Zn}(\mathrm{CN})_{4}^{2-}
$$

Proses Zn Presipitation dilakukan berdasarkan deret Clenel. Deret ini dituliskan sebagai berikut :

$\mathrm{Li}, \mathrm{K}, \mathrm{Ba}, \mathrm{Ca}, \mathrm{Na}, \mathrm{Mg}, \mathrm{Al}, \mathrm{Zn}, \mathrm{Cr}, \mathrm{Fe}$, $\mathrm{Cd}, \mathrm{Co}, \mathrm{Ni}, \mathrm{Sn}, \mathrm{Pb}, \mathrm{Sb}, \mathrm{Bi}, \mathrm{Cu}, \mathrm{Hg}, \mathrm{Ag}$, $\mathrm{Pt}, \mathrm{Au}$

Deret ini dibuat berdasarkan urutan aktivitas elektron logam dalam larutan sianida (cyanide), dengan urutan semakin kekiri letak logam pada deret clenel maka akan semakin mudah berikatan dengan larutan sianida. Konsep diatas dipakai untuk melakukan proses Merryl Crowe yang menggunakan serbuk Zinc (Zn) untuk menggantikan posisi emas $(\mathrm{Au})$ dan perak (Ag) yang terlarut dalam larutan sianida pada proses leaching.

Menurut Drok dan Ritchie pelarutan tembaga umumnya terkendali oleh difusi ion sianida menuju antarmuka reaksi bila konsentrasi sianida dibawah $1 \mathrm{mM}$ dan difusi oksigen terlarut pada konsentrasi oksigen terlarut diatas $6 \mathrm{mM}$. Tembaga terlarut oleh sianida dapat mempengaruhi recovery emas dari larutan kaya hasil pelindian pada proses Merrill Crowe. Pada proses Merrill Crowe tembaga akan terpresipitasi dengan Au dan Ag sehingga menyebabkan konsumsi serbuk seng meningkat.

Proses sementasi tembaga terlarut oleh serbuk seng berlangsung melalui reaksi kimia berikut:

$$
\begin{aligned}
& 2 \mathrm{Cu}(\mathrm{CN}) 2-(\mathrm{aq})+\mathrm{Zn}(\mathrm{s}) \rightarrow \\
& \mathrm{Zn}(\mathrm{CN}) 42-(\mathrm{aq})+\mathrm{Cu}(\mathrm{s})
\end{aligned}
$$

Produk reaksi pengendapan $\mathrm{Cu}$ terlarut akan ikut bersama-sama dengan presipitat $\mathrm{Au}-\mathrm{Ag}$ dan menjadi unsur pengotor dalam dore bullion. Pada saat presipitat dilakukan pengeringan dan kalsinasi, tembaga dan logam-logam pengotor lainnya yang lebih mulia dari seng ikut mengendap bersama Au dan Ag, seperti besi dan timbal akan teroksidasi membentuk oksida-oksidanya baik oksida sederhana maupun oksida kompleksnya.

\subsection{Acid wash}

Pada cake produk proses merril crowe banyak mengandung tembaga sehingga mengurangi kadar emas pada dore bullion yang dihasilkan, hal ini terjadi karena pada deret Clenel terdapat 2 logam yang dalam larutan kaya memilki kandungan cukup banyak selain emas( $\mathrm{Au})$ dan perak(Ag) yang berada pada sebelah kanan unsur zinc(Zn) yang tentunya akan ikut terendapkan dalam proses Merril crowe yang nantinya akan mengganggu kemurnian dari Bullion sebagai produk akhir proses. Logam yang disebutkan diatas adalah Tembaga $(\mathrm{Cu})$ dan Besi(Fe). Treatment yang dilakukan untuk dua unsur ini sebagai berikut:

- Besi (Fe) dihilangkan dengan pengoptimalan jumlah serbuk zinc pada proses. Terlihat pada deret clenel posisi Fe tidak jauh dari $\mathrm{Zn}$ berbeda dengan $\mathrm{Au}, \mathrm{Ag}$, dan $\mathrm{Cu}$ yang berada jauh dikanan. Hal ini menunjukan bahwa aktivitas elektron dari Fe dalam sianida tidak jauh berbeda dengan $\mathrm{Zn}$ oleh karena itu Fe dapat diminimalisir keberadaannya dalam cake dengan mengoptimalkan jumlah serbuk zinc pada proses Merril crowe.

- Tembaga $(\mathrm{Cu})$ tidak bisa dihilangkan dengan treatment khusus pada proses Merryl Crowe, oleh karena itu harus dilakukan proses lanjutan untuk meminimalisir unsur $\mathrm{Cu}$ pada cake. Proses ini dinamakan Acid wash 
Proses Acid wash dimaksudkan untuk menghilangkan unsur yang tidak diinginkan ada dalam cake. Dalam kasus ini unsur yang tidak diinginkan adalah tembaga $(\mathrm{Cu})$.

Pemilihan asam pada proses ini didasarkan pada asam yang bisa melarutkan logam tembaga $(\mathrm{Cu})$, pada penelitian ini digunakan asam sulfat $\left(\mathrm{H}_{2} \mathrm{SO}_{4}\right)$ dikarenakan asam sulfat $\left(\mathrm{H}_{2} \mathrm{SO}_{4}\right)$ cukup selektif terhadap tembaga dan mempunyai kelebihan bisa didaur ulang dari gasnya. Adapun reaksi yang terjadi pada proses ini adalah:

$$
\begin{gathered}
\mathrm{Cu}(\mathrm{s})+2 \mathrm{H}_{2} \mathrm{SO}_{4}(\mathrm{aq}) \rightarrow \mathrm{Cu}^{2+}(\mathrm{aq})+ \\
\mathrm{SO}_{4}{ }^{2-}(\mathrm{aq})+\mathrm{SO}_{2}(\mathrm{~g})+2 \mathrm{H}_{2} \mathrm{O}(\mathrm{aq})
\end{gathered}
$$

\section{METODE PENELITIAN}

Penelitian ini dilakukan dengan cara studi pustaka terhadap berbagai literatur yang berkaitan dengan tema dan tujuan penelitian dengan variasi parameter berupa konsentrasi asam sulfat, kecepatan pengadukan, dan persen solid.

Adapun prosedur percobaanya adalah:

1. Siapkan sampel cake seberat 200gram dengan fraksi ukuran p80 200\#

2. Siapkan larutan asam sulfat yang diencerkan dengan pengenceran $(1 \mathrm{x}$, $3 \mathrm{x}, 5 \mathrm{x}, 10 \mathrm{x}$ dan $15 \mathrm{x}$ terhadap mol logam pengotor dalam cake)
3. Masukan sampel cake kedalam reactor, dan pastikan impeller yang digunakan dalam keadaan bersih

4. Nyalakan impeller dan masukan asam sulfat kedalam reactor

5. Lakukan pengambilan sampel larutan sebanyak $10 \mathrm{ml}$ pada menit ke- 10, 20, 30, 40, 50 dan 60.

6. Sampel yang diambil lalu dilakukan filtrasi dengan kertas saring dan labu Erlenmeyer yang disambungkan dengan vacuum filtration. Lalu, larutan yang sudah terpisahkan diencerkan dan dianalisis menggunakan AAS

7. Setelah 60 menit, dilakukan difiltrasi untuk memisahkan padatan dan larutan. Residu dianalisis kandungan logam yang masih tersisa didalamnya

8. Menghitung persen eliminasi logam pengotor sebagai fungsi waktu

\section{HASIL PERCOBAAN}

Hasil percobaan disini mengutip data hasil percobaan oleh Annisa Ikrima Ulva dengan judul penelitian "Penurunan Kadar Tembaga Dan Seng Dalam Presipitat Emas-Perak Hasil Proses Merril crowe Dengan Metode Digesti Dalam Larutan Asam Sulfat" 
Journal Of Metallurgical Engineering And Processing Technology, Vol. ..., No...., Month 20XX, pp. ...-...

P-ISSN: $x$, E-ISSN: $x$

\subsection{Analisis Cake Hasil Merril crowe}

Tabel 4.1 Hasil analisis kadar emas perak (head grade) menggunakan fire assay dan kadar pengotor menggunakan AAS pada sampel cake

\begin{tabular}{lcccccc}
\hline \multirow{2}{*}{ JENIS } & $\mathbf{A u}$ & $\mathbf{A g}$ & $\mathbf{C u}$ & $\mathbf{F e}$ & $\mathbf{P b}$ & $\mathbf{Z n}$ \\
\cline { 2 - 7 } & $\mathbf{p p m}$ & $\mathbf{p p m}$ & $\mathbf{\%}$ & $\mathbf{p p m}$ & $\mathbf{p p m}$ & $\%$ \\
\hline Cake 1 & 2040 & 1380 & 1,44 & 1500 & 1010 & 0,42 \\
Cake 2 & 1560 & 1240 & 6,12 & 8990 & 935 & 2,82 \\
Cake 3 & 1730 & 850 & 4,7 & 5000 & 1000 & 1,58 \\
Cake 4 & 1670 & 6830 & 7,07 & 5000 & 2000 & 3,07 \\
Cake 5 & 1710 & 1000 & 7,25 & 5000 & 1000 & 2,12 \\
Cake 6 & 1460 & 1340 & 5,52 & 5000 & 2000 & 2,88 \\
Cake 7 & 1590 & 21100 & 7,45 & 5000 & 1000 & 2,36 \\
Cake 8 & 1390 & 35600 & 6,49 & 37700 & 1400 & 6,78 \\
Cake 9 & 1460 & 217000 & 6,77 & 7800 & 1300 & 1,93 \\
\hline
\end{tabular}

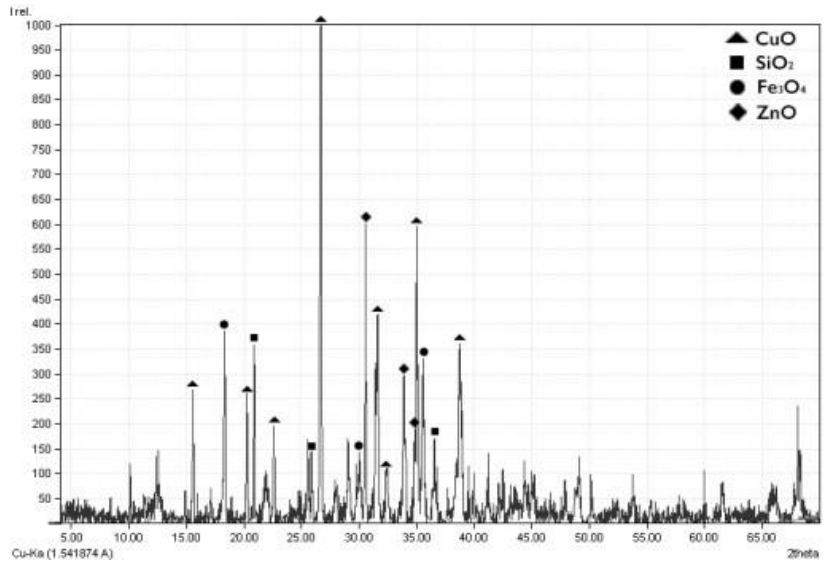

Gambar 4.2 Hasil analisis komposisi kimia cake dengan XRD

Tabel 4.2 Hasil analisis komposisi kimia cake dengan XRF

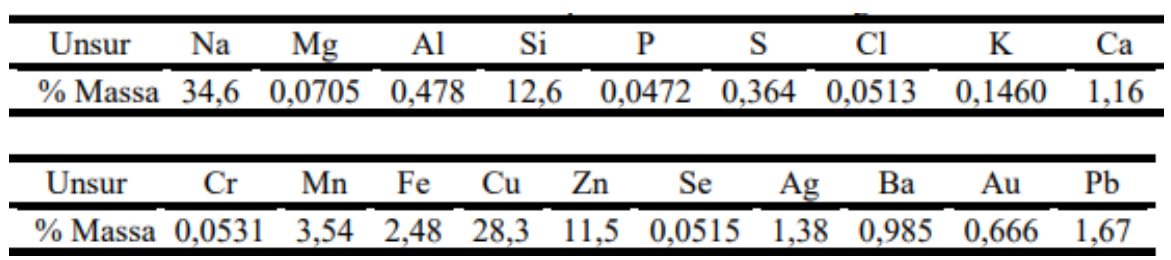


Journal Of Metallurgical Engineering And Processing Technology, Vol. ..., No...., Month 20XX, pp. ...-...

P-ISSN: $x$, E-ISSN: $x$ 
Journal Of Metallurgical Engineering And Processing Technology, Vol. ..., No...., Month 20XX, pp. ...-...

P-ISSN: $x$, E-ISSN: $x$

\subsection{Hasil Acid wash Cake}

Setelah cake dianalisis kadar awalnya, selanjutnya dilakukan analis persen eliminasi pada masing-masing variabel yang telah ditentukan

Tabel 4.3 Hasil persen eliminasi pada kondisi kecepatan pengadukan $100 \mathrm{rpm}$, waktu acid wash 1 jam pada berbagai konsentrasi asam sulfat

\begin{tabular}{|ccccccccccc|}
\hline \multirow{3}{*}{ Waktu } & \multicolumn{10}{c|}{ Persen Eliminasi pada Variasi Stokiometri $\mathrm{H}_{2} \mathrm{SO}_{4}$ dengan Kecepatan Pengadukan 100 rpm } \\
\cline { 2 - 12 } & \multicolumn{7}{c}{$\mathrm{Cu}$} \\
\hline Menit & $1 \mathrm{x}$ & $3 \mathrm{x}$ & $5 \mathrm{x}$ & $10 \mathrm{x}$ & $15 \mathrm{x}$ & $1 \mathrm{x}$ & $3 \mathrm{x}$ & $5 \mathrm{x}$ & $10 \mathrm{x}$ & $15 \mathrm{x}$ \\
\hline 0 & 0,00 & 0,00 & 0,00 & 0,00 & 0,00 & 0,00 & 0,00 & 0,00 & 0,00 & 0,00 \\
10 & 0,20 & 6,61 & 12,90 & 25,51 & 23,43 & 0,32 & 16,23 & 23,69 & 49,56 & 48,58 \\
20 & 0,22 & 9,97 & 19,05 & 37,69 & 34,51 & 0,35 & 36,73 & 38,54 & 51,13 & 56,95 \\
30 & 0,22 & 5,56 & 9,35 & 45,28 & 28,61 & 0,35 & 47,76 & 40,88 & 57,84 & 63,90 \\
40 & 0,23 & 8,45 & 9,82 & 33,31 & 29,27 & 0,41 & 53,23 & 52,77 & 64,77 & 65,26 \\
50 & 0,24 & 11,09 & 17,73 & 35,06 & 31,97 & 0,43 & 58,02 & 56,42 & 68,50 & 66,89 \\
60 & 0,25 & 14,03 & 22,01 & 43,24 & 35,05 & 0,44 & 58,94 & 55,33 & 67,64 & 68,01 \\
\hline
\end{tabular}

Tabel 4.4 Hasil persen eliminasi pada kondisi kecepatan pengadukan 100 rpm, waktu acid wash 1 jam pada berbagai konsentrasi asam sulfat

\begin{tabular}{|c|cccc|}
\hline \multirow{2}{*}{ Waktu } & \multicolumn{3}{|c|}{$\begin{array}{c}\text { Persen Eliminasi pada Persen Padatan dalam 1 Jam digest, } \\
10 \mathrm{~N} \mathrm{H}_{2} \mathrm{SO}_{4} \text { dan 300 rpm }\end{array}$} \\
\cline { 2 - 5 } & \multicolumn{3}{|c|}{ 200 rpm } & \multicolumn{3}{c|}{$300 \mathrm{rpm}$} \\
\cline { 2 - 5 } & $\mathrm{Cu}$ & 0,00 & 0,00 & 0,00 \\
\hline 0 & 0,00 & 43,18 & 41,71 & 54,92 \\
10 & 29,69 & 53,25 & 50,60 & 64,42 \\
20 & 43,89 & 55,56 & 46,64 & 66,20 \\
30 & 48,30 & 63,50 & 52,01 & 71,86 \\
40 & 53,55 & 56,85 & 42,40 & 69,60 \\
50 & 38,64 & 69,32 & 50,31 & 68,84 \\
60 & 46,37 & \multicolumn{3}{c}{} \\
\hline
\end{tabular}

Tabel 4.5 Hasil persen eliminasi pada variasi persen padatan pada konsentrasi $\mathrm{H}_{2} \mathrm{SO}_{4} 10 \mathrm{x}$ stokiometri, kecepatan pengadukan $300 \mathrm{rpm}$ dan 1 jam acid wash

\begin{tabular}{|ccccccccc|}
\hline \multirow{2}{*}{ Waktu } & \multicolumn{3}{c|}{ Persen Eliminasi pada Persen Padatan dalam 1 Jam digest, 10x H $\mathrm{SO}_{4}$ dan $300 \mathrm{rpm}$} \\
\cline { 2 - 10 } & \multicolumn{3}{c}{$\mathrm{Cu}$} & \multicolumn{5}{c|}{$\mathrm{Zn}$} \\
\hline Menit & $30 \%$ & $35 \%$ & $40 \%$ & $45 \%$ & $30 \%$ & $35 \%$ & $40 \%$ & $45 \%$ \\
\hline 0 & 0,00 & 0,00 & 0,00 & 0,00 & 0,00 & 0,00 & 0,00 & 0,00 \\
10 & 25,46 & 17,92 & 5,01 & 3,23 & 48,52 & 57,47 & 16,12 & 23,05 \\
20 & 30,03 & 26,48 & 2,91 & 4,13 & 48,10 & 57,47 & 17,35 & 29,38 \\
30 & 31,49 & 31,81 & 10,21 & 4,60 & 47,65 & 57,47 & 48,16 & 34,05 \\
40 & 30,90 & 23,40 & 7,92 & 6,11 & 51,07 & 54,52 & 46,94 & 39,17 \\
50 & 32,65 & 24,63 & 9,15 & 6,49 & 52,16 & 57,47 & 46,12 & 36,15 \\
60 & 32,65 & 30,38 & 9,56 & 6,35 & 61,64 & 57,47 & 46,94 & 41,58 \\
\hline
\end{tabular}




\section{PEMBAHASAN}

\subsection{Analisa Sampel Cake}

Hasil fire assay head grade cake merril crowe menunjukan bahwa kandungan $\mathrm{Cu}$ pada sampel cukup tinggi yaitu berkisar antara 1,44-7,45\%. Kadar $\mathrm{Cu}$ tertinggi terdapat pada cake 7 yaitu 7,45\% dan terendah pada cake 1 yaitu $1,44 \%$. Selain $\mathrm{Cu}$ terdapat juga logam pengotor $\mathrm{Zn}$ yang cukup tinggi yaitu berkisar antara 0,42\%-6,78\% dengan total rata-rata sebesar $2,66 \%$.

Hasil analisis XRD menunjukan senyawa yang dominan pada cake adalah senyawa oksida seperti $\mathrm{CuO}, \mathrm{ZnO}, \mathrm{SiO}$, dan $\mathrm{Fe} 3 \mathrm{O} 4$. Berdasarkan analisis XRF didapatkan data unsur tertinggi adalah $\mathrm{Na}(34,6 \%)$, diikuti unsur $\mathrm{Cu}$ yaitu $28,3 \%$, Si yaitu $12,6 \%$ dan Zn 11,5\%.

Berdasarkan hasil fire assay, xrd, dan xrf diketahui bahwa sampel cake hasil merril crowe masih memiliki kandungan base metal berupa $\mathrm{Cu}, \mathrm{Fe}, \mathrm{Pb}$, $\mathrm{Zn}$ yang relatif tinggi, dimana $\mathrm{Cu}$ merupakan pengotor utama pada cake dengan kadar rata-rata tertinggi.

\subsection{Analisa Konsentrasi $\mathrm{H}_{2} \mathrm{SO}_{4}$}

Persen eliminasi $\mathrm{Cu}$ dan $\mathrm{Zn}$ sebagai fungsi waktu pada berbagai konsentrasi asam sulfat untuk proses acid wash cake dengan variasi konsentrasi asam sulfat pada kecepatan pengadukan $100 \mathrm{rpm}$ dan waktu acid wash 1 jam didapatkan persen eliminasi $\mathrm{Cu}$ tertinggi sebesar $43,24 \%$ dan persen eliminasi $\mathrm{Zn}$ tertinggi sebesar $68,01 \%$. Dimana $\mathrm{Cu}$ tertinggi didapatkan dengan konsentrasi asam 10x stokiometri sedangkan $\mathrm{Zn}$ tertinggi didapatkan dengan konsentrasi asam $15 \mathrm{x}$ stokiometri. Persen kehilangan $\mathrm{Au}$ paling tinggi yaitu $0,1 \%$ diperoleh pada konsentrasi asam 10x stoikiometri, sementara persen kehilangan Ag paling tinggi yaitu $21,93 \%$ diperoleh pada $15 x$ stokiometri reaksi.

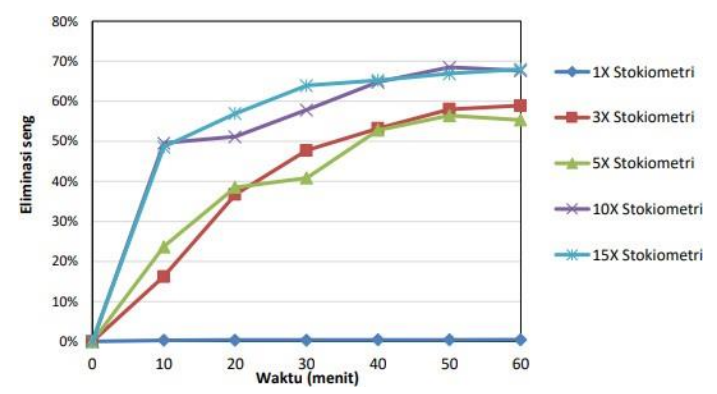

Gambar 5.1 Grafik persen eliminasi $\mathrm{Cu}$ pada berbagai konsentrasi asam sulfat selama 60 menit

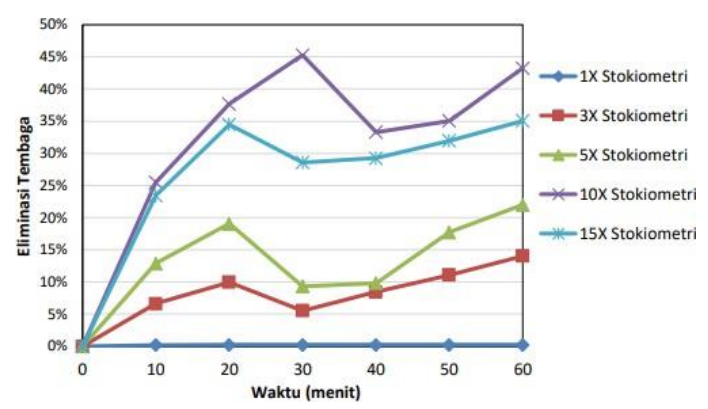

Gambar 5.2 Grafik persen eliminasi Zn pada berbagai konsentrasi asam sulfat selama 60 menit

Terlihat bawa persen eliminasi $\mathrm{Cu}$ meningkat dengan meningkatnya konsentrasi $\mathrm{H}_{2} \mathrm{SO}_{4}$ diantara 1x stokiometri dan 10x stokiometri lalu persen eliminasi menurun pada $15 x$ stokiometri. Pencucian $\mathrm{Cu}$ pada konsentrasi asam yang tinggi menyebabkan meningkatnya viskositas dari larutan sehingga menurunkan laju pelindian. Persen eliminasi $\mathrm{Zn}$ tertinggi sebesar $68,01 \%$ yang diperoleh pada konsentrasi asam $15 \mathrm{x}$ stokiometri. Dikarenakan pengotor yang ingin dihilangkan adalah $\mathrm{Cu}$, maka penulis memilih konsentrasi asam sulfat $10 x$ 
Journal Of Metallurgical Engineering And Processing Technology, Vol. ..., No....,

Month 20XX, pp. ...-...

P-ISSN: $x$, E-ISSN: $x$

stokiometri pada percobaan untuk variabel selanjutnya.

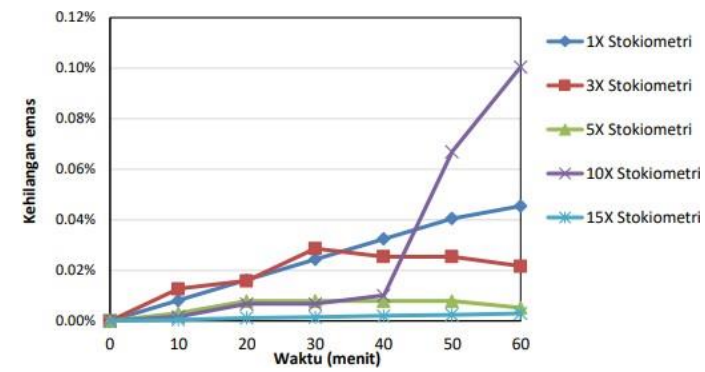

Gambar 5.3 Grafik persen eliminasi $\mathrm{Au}$ pada berbagai konsentrasi asam sulfat selama 60 menit

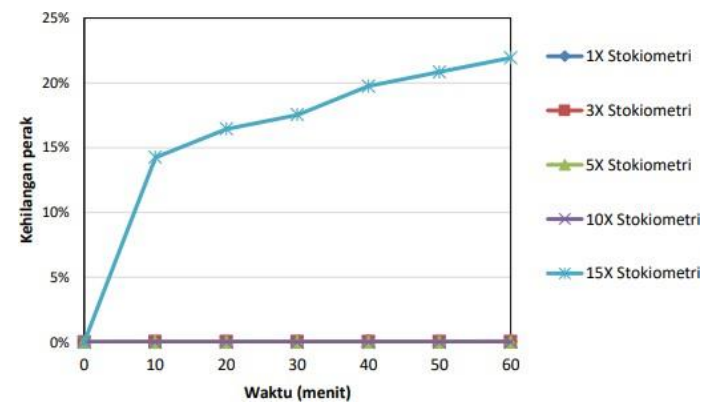

Gambar 5.4 Grafik persen eliminasi Ag pada berbagai konsentrasi asam sulfat selama 60 menit

$\mathrm{Au}$ dan Ag dapat terlarut dalam larutan asam apabila Au dan Ag dalam kondisi teroksidasi dan proses pelarutan yang dilakukan dengan menggunakan asam pekat serta suhu yang tinggi. Berdasarkan diagram Eh-pH pada suhu $25^{\circ} \mathrm{C}$, Au stabil pada kondisi $\mathrm{pH} 0-14$ dan kondisi terlarutnya hanya bergantung kepada nilai potensial larutan. Pada $25^{\circ} \mathrm{C}$ dan 1 atm, $\mathrm{Au}$ teroksidasi menjadi ion $\mathrm{Au}+$ pada potensial $1,68 \mathrm{~V}$ vs $\mathrm{SHE}$, sementara $\mathrm{Ag}$ teroksidasi menjadi ion $\mathrm{Ag}+$ pada potensial $0,797 \mathrm{~V}$. Berdasarkan nilai potensial reduksinya, Ag akan lebih mudah terkonversi menjadi ionnya daripada $\mathrm{Au}$ sehingga pada variasi $15 \mathrm{x}$ stokiometri persen pelarutan $\mathrm{Ag}$ signifikan lebih tinggi dibandingkan dengan Au.

\subsection{Analisa Kecepatan Pengadukan}

Dari variabel sebelumnya, dapat diketahui 10x stokiometri konsentrasi $\mathrm{H}_{2} \mathrm{SO}_{4}$ dan kecepatan 100 rpm menghasilkan keadaan optimum untuk proses acid wash, dari keadaan optimum ini penulis melakukan variasi kecepatan pengadukan $200 \mathrm{rpm}$ dan $300 \mathrm{rpm}$ selama 1 jam dengan konsentrasi asam 10x stokiometri, dari percobaan ini, didapatkan hasil sebagai berikut:

Pada kecepatan pengadukan 300 rpm selama 1 jam dan konsentrasi 10x stokiometri didapatkan eliminasi $\mathrm{Cu}$ dan $\mathrm{Zn}$ tertinggi yaitu masing-masing sebesar $68,84 \%$ dan 50,31\%. Hasil percobaan menunjukkan bahwa seiring dengan meningkatnya kecepatan pengadukan, persen eliminasi $\mathrm{Cu}$ dan $\mathrm{Zn}$ cenderung meningkat. Peningkatan kecepatan pengadukan meningkatkan intensitas kontak antara partikel cake dengan larutan asam sulfat dan menurunkan ketebalan film difusi pada permukaan partikel padat.

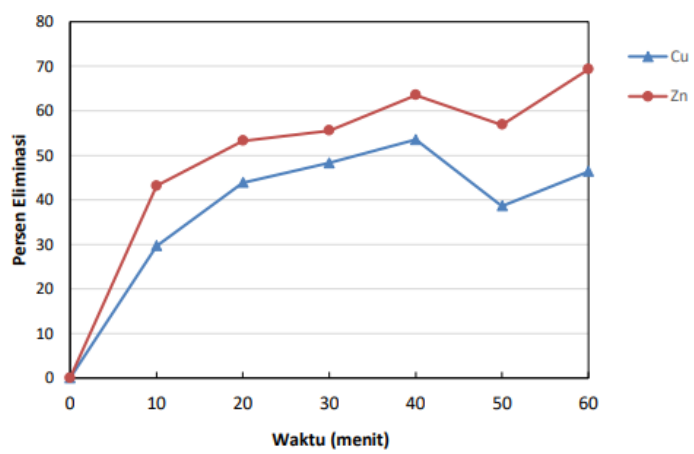

Gambar 5.5 Grafik persen eliminasi $\mathrm{Cu}$ dan Zn pada kecepatan pengadukan 200 rpm selama 1 jam dengan konsentrasi $\mathrm{H}_{2} \mathrm{SO}_{4} 10 x$ stoikiometri 


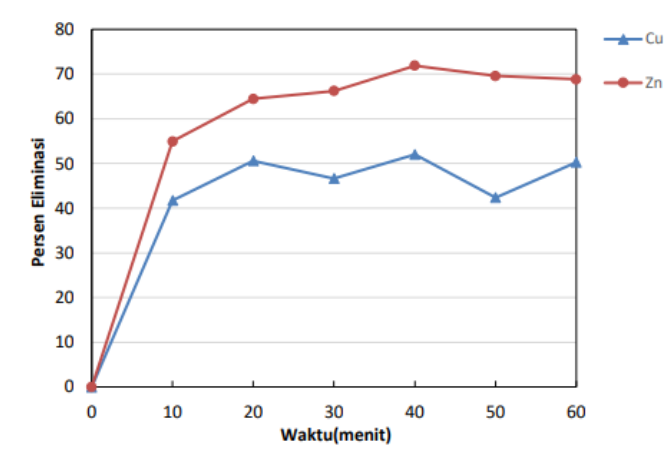

Gambar 5.6 Grafik persen eliminasi $\mathrm{Cu}$ dan $\mathrm{Zn}$ pada kecepatan pengadukan 300 rpm selama 1 jam dengan konsentrasi

$\mathrm{H}_{2} \mathrm{SO}_{4} 10 x$ stoikiometri

\subsection{Analisa Persen Solid}

Proses acid wash cake dengan variasi persen solid dilakukan dengan variabel waktu 1 jam, kecepatan pengadukan $300 \mathrm{rpm}$, dan konsentrasi asam 10x stokiometri. Dari percobaan ini, didapatkan hasil sebagai berikut:

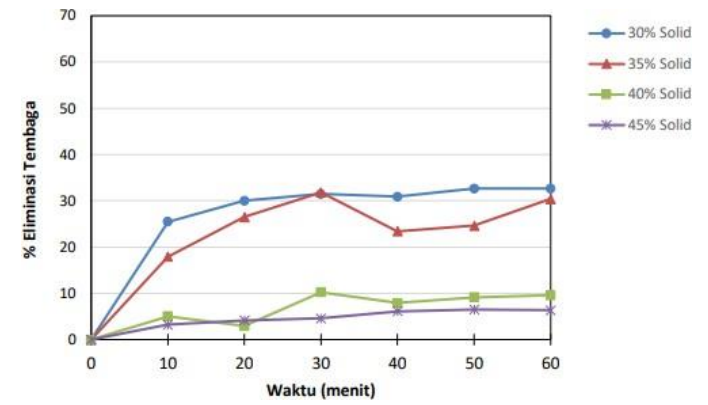

Gambar 5.7 Grafik persen eliminasi $\mathrm{Cu}$ pada variasi persen solid dengan kecepatan pengaduk $300 \mathrm{rpm}$ dan selama 1 jam

Persen eliminasi $\mathrm{Cu}$ dan $\mathrm{Zn}$ yang optimum didapat pada persen solid $30 \%$. Persen eliminasi $\mathrm{Cu}$ dan $\mathrm{Zn}$ cenderung turun dengan kenaikan persen padatan pada rentang 30\%-45\%. Persen eliminasi $\mathrm{Cu}$ dan $\mathrm{Zn}$ tertinggi didapat pada persen solid $30 \%$ yaitu masing-masing sebesar
$32,65 \%$ dan $61,64 \%$. Hal ini disebabkan oleh meningktnya persen padatan akan meningkatkan viskositas suspensi resistensi perpindahan massa spesi yang bereaksi ke antarmuka reaksi semakin tinggi.

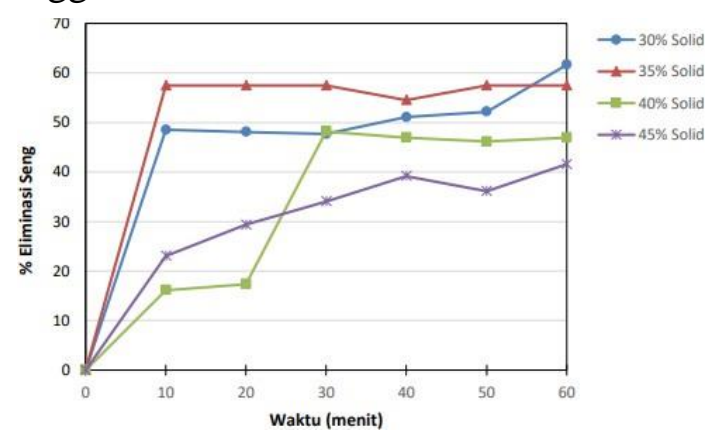

Gambar 5.8 Grafik persen eliminasi Zn pada variasi persen solid dengan kecepatan pengaduk $300 \mathrm{rpm}$ dan selama 1 jam

Persen eliminasi $\mathrm{Cu}$ dan $\mathrm{Zn}$ yang optimum didapat pada persen solid $30 \%$. Persen eliminasi $\mathrm{Cu}$ dan $\mathrm{Zn}$ cenderung turun dengan kenaikan persen padatan pada rentang 30\%-45\%. Persen eliminasi $\mathrm{Cu}$ dan $\mathrm{Zn}$ tertinggi didapat pada persen solid $30 \%$ yaitu masing-masing sebesar $32,65 \%$ dan $61,64 \%$. Hal ini disebabkan oleh meningktnya persen padatan akan meningkatkan viskositas suspensi resistensi perpindahan massa spesi yang bereaksi ke antarmuka reaksi semakin tinggi.

\section{KESIMPULAN}

Dari kajian pustaka yang dilakukan, dapat diambil beberapa kesimpulan:

1. Cake hasil pengolahan PT NHM mengandung pengotor base metal berupa $\mathrm{CuO}, \mathrm{Fe} 3 \mathrm{O} 4, \mathrm{ZnO}$, dan senyawa kompleks yang berikatan dengan $\mathrm{Cu}$ dan $\mathrm{Zn}$ 
2. Kondisi proses acid wash yang optimum didapat pada konsentrasi 10x stokiometri $\mathrm{H} 2 \mathrm{SO} 4$, persen padatan $30 \%$, kecepatan pengadukan $300 \mathrm{rpm}$, dan waktu acid wash 1 jam yang menghasilkan persen eliminasi $\mathrm{Cu}$ dan $\mathrm{Zn}$ masing-masing sebesar 53,31\% dan 68,84\%.

3. Persen Kehilangan $\mathrm{Au}$ tertinggi terdapat pada konsentrasi asam 10x stokiometri yaitu sebesar $0,1 \%$ sedangkan $\mathrm{Ag}$ terdapat pada konsentrasi asam $15 \mathrm{x}$ stokiometri yaitu sebesar 21,93\%. Sedangkan persen eliminasi $\mathrm{Au}$ dan $\mathrm{Ag}$ yang terendah terdapat pada konsentrasi asam 1x stokiometri yaitu masing-masing sebesar $0,02 \%$ dan $0,07 \%$

4. Acid wash cake menggunakan $\mathrm{H}_{2} \mathrm{SO}_{4}$ bisa mengurangi kadar pengotor $\mathrm{Cu}$ hingga $53,31 \%$ dan Zn hingga $68,84 \%$. Hal ini bisa jadi pertimbangan oleh pihak perusahaan untuk mengurangi biaya pemurnian dore bulion

\section{UCAPAN TERIMAKASIH}

Penulis mengucapkan terimakasih yang sebesar-besarnya kepada:

1. Ibu Tri Wahyuningsih sebagai dosen pembimbing dalam penulisan jurnal ini,

2. Ibu Anggia Magnalita Octaviani selaku pembimbing dari PT NHM bidang project metallurgist,

3. Berbabgai pihak yang telah ikut berpartisipasi membantu kelancara kegiatan penelitian, baik secara langsung maupun tidak langsung

\section{SARAN}

Masih terdapat beberapa hal yang perlu diteliti lebih lanjut. Berikut ini adalah saran-saran untuk penelitian selanjutnya:

1. Melakukan penelitian lebih lanjut dengan variabel $5 \mathrm{x}$ konsentrasi asam sulfat, 30\% persen solid, dan $300 \mathrm{rpm}$ kecepatan pengadukan, dikarenakan pada kondisi 5\% konsentrasi asam sulfat memiliki persen kehilangan $\mathrm{Au}$ dan $\mathrm{Ag}$ yang lebih rendah

2. Melakukan penelitian lebih lanjut menggunakan variabel yang berbeda, seperti menggunakan asam lain, variasi konsentrasi asam, dll

3. Melakukan proses acid wash dengan suhu diatas suhu ruangan

\section{DAFTAR PUSTAKA}

J, Yannopoulos. 1991. The Extractive Metallurgy of Gold. Springer. (Chapter 10)

C.J. Kim, H.S. Yoon, K.W. Chung, J.Y. dkk. 2014. Leaching Kinetics of Lanthanum in Sulfuric Acid from Rare Earth Element (REE) Slag. Hydrometallurgy 146, 133-137.

Mpinga, C. N., Bradshaw, S. M., Akdogan, G., Snyders, C. A., \& Eksteen, J. J. (2014). Evaluation of the Merrill-Crowe process for the simultaneous removal of platinum, palladium and gold from cyanide leach solutions. Hydrometallurgy, 142, 36-46. doi:10.1016/j.hydromet.2013.11. 004

Ulva, Annisa Ikrima. 2019. Penurunan Kadar Tembaga Dan Seng 
Journal Of Metallurgical Engineering And Processing Technology, Vol. ..., No...., Month 20XX, pp. ...-...

P-ISSN: $x$, E-ISSN: $x$

Dalam Presipitat Emas-Perak

Hasil Proses Merril crowe

Dengan Metode Digesti Dalam

Larutan Asam Sulfat [Skripsi].

Bandung: Institut Teknologi

Bandung 